\title{
MENTOR MORA V NEKEM TRENUTKU OPUSTITI VODENJE ŠTUDENTOVE ROKE Pogovor z Miranom Eričem o skupini Želva in o tem, kako postati mentor
}

$\mathrm{M}$

ag. Miran Erič, akademski slikar, ima za seboj izobraževalno in življenjsko pot, za katero ne moremo reči, da ga je vodila naravnost $\mathrm{k}$ ciljem. Vila se je $\mathrm{v}$ iskanju, odkrivanju in mimo srečnih naključij. In vendar se zdi, da mu je prav ta pot naklonila veliko spoznanj in priložnosti. Več let je študiral na Pedagoški

》Rad se učim od svojih študentov.« fakulteti, potem se je vpisal na Akademijo za likovno umetnost. Na nekem seminarju za konzervatorje je srečal kolega, ki se je prav tako kot on rad potapljal. Navidez običajno srečanje ga je pripeljalo najprej do specialističnega študija in nato še do magistrskega študija s področja konzervacije mokrega lesa. Takrat je pričl hoditi po muzejih, zbirati podatke. Študij je imel poudarek na slikarstvu, vendar je bil predvsem interdisciplinaren. Imel pa je tudi arheološke vidike in tako ga je pot kasneje pripeljala na Oddelek za arheologijo na Filozofski fakulteti v Ljubljani.

A. S.: Za vami je zelo osebna izobraževalna pa tudi življenjska pot. Veliko iskanja in odkrivanja je bilo na tej poti. Povejte, $s$ čim se danes ukvarjate, denimo na Oddelku za arheologijo na Filozofski fakulteti, kjer ste zaposleni? Kaj vas pri vašem delu najbolj navdušuje?

Mislim, da sem, nenazadnje tudi zaradi svojih preteklih izkušenj, ki so mi dale vpogled v ljudi, njihovo obnašanje, razmišljanje in čustva, vzljubil delo s posameznimi študenti. Rad jih spodbujam, rad skupaj z njimi odkrivam pot, takšno, ki je prav njim pisana na kožo. $\mathrm{Ne}$ vem, če bi me veselilo frontalno poučevanje, kjer je predavatelj neizogibno oddaljen od svojih študentov. Kjer je predvsem predavatelj tisti, ki ve, in so študenti neizkušeni in zato nevedni. Pa zakaj bi bili nevedni? Morda zato, ker nimajo za seboj trideset let mojih izkušenj. Rad se učim od svojih študentov in rad vidim, ko se učijo od mene.

A. S.: Sami ste nas poiskali, ker se vam zdi, da ste si $v$ dvajsetih letih vodenja enega prvih slikarskih študijskih krožkov na Univerzi za tretje življenjsko obdobje nabrali veliko izkušenj, ki ste jih zmeraj pospremi- 
li s poglobljeno refleksijo in posplošitvami. Te bi želeli prenesti tudi na druge. Vas je $k$ temu koraku napotilo še kaj drugega?

$\mathrm{Ja}$, če prav pomislim, me je pri tem vodilo tudi to, da se želim upreti trdovratnemu negativnemu pogledu na slikarje v zrelih letih. Skupina Želva, s katero sem preživel celih dvajset let, je postala skupina dobrih slikarjev, Najpomembneje je, da se je v dvajsetih letih močno razvilo njihovo slikarsko mišljenje. Uporabljajo ga pri slikanju in odkrivanju del drugih slikarjev, kiparjev, arhitektov. Njihova pridobljena estetska merila vplivajo na njihovo mišljenje. Na njih in tudi na njihovo socialno okolje. To se mi zdi pomembno. Sprašujem pa se, zakaj? ... Zakaj uradni kritiki, umetnostni zgodovinarji, uredniki kulturnih oddaj in drugi ne zmorejo zanimanja za delo tistih, ki so $v$ pokoju. Meni se zdi, da jih vidijo kot »neživečo« skupino ljudi. Kot da bi bili že mrtvi. A pred njimi je deset, dvajset, morda trideset let življenja. Si lahko zamislite, koliko fakultet bi lahko človek končal v tem času. Saj ne pričakujem, da bi o teh slikarjih v zrelih letih pisali eseje, a vsaj kakšno kritiko. Tudi, če bi rekli, da je vse zanič in neumno, bi to spodbudilo vnemo skupine. Tako pa ... Ne bi rad, da bi mene ali moje otroke tako obravnavali $v$ starosti. Zato se po svojih močeh trudim te predsodke razbiti. Zdajle ima skupina Želva razstavo v KUD-u France Prešeren. Naslovili smo jo Potreti. Še ena razstava med mnogimi, ki so obogatile skupino samo pa tudi kulturni program te ustanove.

A. S.: Kako in kdaj ste spoznali, da so starejši »močno živeča« in motivirana družbena skupina, če jim le malo pomagamo, da se uprejo nasilju družbenih stereotipov, ki jih silijo v pasivnost in odvisnost.

Spominjam se začetkov Univerze za tretje življenjsko obdobje. Takrat smo delali v nekem domu starejših. Vsake toliko je kakšna radovedna glava domskega oskrbovanca pogledala v prostor. Med oskrbovanci, ki so ži- veli za zidovi tega doma, in mojimi študenti je bila velika razlika. Moji študenti so bili živega duha. Iskrila so se zanimanja. Želja ustvariti nekaj dobrega, učiti se, razvijati se. Takrat sem prišel do prvega spoznanja. Če želimo, da bi bili starejši del družbe, da bi ustvarjali in se razvijali, potem jim moramo odpreti vrata $v$ središče življenja. Zato je tudi treba najti prostore $v$ središč mesta $v$ okoljih, kjer so starejši lahko tudi prostorsko povezani $z$ ljudmi drugih starosti in z njihovim delovanjem, da nastane pretok med njimi. Ljudje smo
»Sleherni med nami je vir učenja za druge.« od nekdaj, četudi različnih starosti, živeli in delali skupaj. Komaj industrijsko obdobje je prineslo umetne ločnice med ljudmi različnih starosti. Danes drug drugega potrebujemo in sleherni med nami je vir učenja za druge. Starejši še prav posebno. Ni res, da so vredne le današnje izkušnje, kot danes pričenjamo slepo verjeti. Starejši imajo pogled na svet okrog sebe, pa tudi na prihodnost. Prisluhnimo jim, kakor prisluhnemo sebi in laže se bomo odločali.

\section{A. S.: Rekli ste, naj bodo starejšsi v središču življenja. Kako ste vi poskrbeli za to?}

No, mi smo se sprva programsko povezali z Osnovno šolo Trnovo. Spominjam se, da smo skupaj z otroki slikali na isto temo. Dolgo časa smo gostovali v njihovih prostorih. Potem pa mi je prišlo na misel, da sem vendarle dejaven član KUD-a France Prešeren. Sodeloval sem tudi v gledališču Ane Monro in tako se je tudi skupina Želva preselila tja. To je spremenilo programsko politiko tega kulturno-umetniškega društva. Postala je pravi »community center«. Odprla je vrata delovanju vseh in nastal je program, ki so ga poimenovali $O d l$ do 99. V prepričanju, da lokalni razvoj sloni na ljudeh vseh starosti in vseh družbenih skupin, ter v prepričanju, da je poleg uradne kulture potrebna tudi ona druga, ki jo ustvarjajo prebivalci, so slednje povabili, naj sodelujejo $\mathrm{v}$ 
pripravi letnega programa. Moja skupina se je tega takoj lotila in od takrat redno delujemo tam. Vsako leto prispevamo razstavo. Letošnja je imela naslov Potreti.

\section{A. S.: Za vami je dolga pot dela $\mathrm{z}$ eno samo skupino. Ste si na začetku predstavljali, da bo tako dolga?}

$\mathrm{Ne}$, to pa res ne! V glavi sem imel, saj veste, tisto poznano shemo, da se izobražujemo neko število let. Osem let, štiri leta pa še štiri leta itd. Vsakič dosežemo predpisane cilje. Res si nisem predstavljal, da bodo ljudje prihajali $\mathrm{k}$ meni po znanje in da bo hkrati nadvse

\section{Razvoj je mogoč le iz tistega, kar ima- mo, in ne iz tiste- ga, cesar nimamo.} pomembno, da se družimo, da prihajajo na določen dan. Izbrali so si torek ... Takrat pridejo s svojimi mapami, obteženi s čopiči in barvami. To je njihov dan. Zlagoma pa je torek postal tudi moj dan, ki ga ni moč zamenjati za katerega drugega. Življenja ni moč prestavljati, saj veste. Zakaj? Zato, ker je za starejše ljudi učenje, izobraževanje, $v$ našem primeru slikanje $v$ skupini tudi način življenja. Ob tem spoznanju sem se vprašal tudi, kakšna pa je potem vloga učitelja oziroma mentorja $v$ takšni skupini? Vsekakor širša od tiste, ki sem si jo predstavljal na začetku. Zase mislim, da sem postal vodja, svetovalec, most med njimi in stvaritvami, dogodki v mestu itd. Včasib rešujem tudi kakšno psiho-patološko stanje, ki navadno nastane $\mathrm{v}$ tej družbeni skupini zaradi hude deprivacije psiho-socialnih potreb. Učitelj $v$ takšni skupini je bolj animator, takšen, ki ljudi povezuje, navdušuje, jih vodi, skupaj z njimi določa cilje in vsebino skupnega dela, pozna njihovo življenje. Zanimivo pa je, da ga skupina sprejme tudi kot svojega člana. In tako skupina rešuje tudi njegova vprašanja in vstopa v njegovo življenje. Skratka, nastajajo medsebojni odnosi, vzajemno učenje, doživljanje. Skupna strokovna in deloma tudi skupna življenjska pot.

\section{A. S.: Ste bili že na začetku poti takšnega mnenja?}

Kje pa! Prvih pet let sem se ukvarjal predvsem s svojimi ambicijami. Če bi nekdo takrat na začetku rekel, da bom dvajset let ostal s skupino Želva, bi mu rekel, da je nor. Prišel sem nabit z vtisi iz svojega šolanja in poln izkušenj s poučevanjem v osnovni šoli. $\mathrm{Pa}$ tudi naša mama je bila pedagoginja in jaz sem njeno znanje srkal vase. No, že tako dolgo se učim in znanje prenašam na druge, da tega pedagoškega znanja ne morem več odvreči; četudi bi hotel, ne bi šlo. Sprva se mi je zdelo, da je najpomembnejšs program. V prvem tednu se bomo naučili tega in onega, v drugem tednu, čez leto dni ... Sami etapni cilji. In na koncu bodo vsi akademski slikarji. Skorajda. Bil sem egoist, takšen kot večina pedagogov, Skrbel sem za svoja hotenja. Vendar, dokler sem skrbel za svoje ambicije, sem imel težave. Besno sem hitel dalje in se vsake toliko ozrl, da vidim, če tečejo za menoj. Vlekel sem in se spraševal. "Kje ste?" Potem pa sem začutil, da je nekaj močno narobe. In kmalu smo se začeli pogovarjati. O tem, kako se učijo, kaj občutijo, česa si želijo. To je bil prvi zlom na moji začrtani poti. In prišel sem do spoznanja, da so v pedagoškem procesu najpomembnejši tisti, ki se učijo. Njim naj bo vse podrejeno. Ne smemo jih siliti $v$ tisto, do česar jim ni. V čemer, verjetno tudi z veliko truda, ne bodo postali dobri. Imam študentko, ki se ne more naučiti perspektive, Ne more pa pika. Pa kaj zato! Ima pa posebnost. Ima težave $\mathrm{z}$ vidom in $\mathrm{z}$ enim očesom vidi na nek in $z$ drugim spet na nek drug način, pod drugačnimi koti. Posledica hude gripe. Ja, v tem je njena posebnost. Mnogi slikarji bi si želeli gledati in videti tako. Pod različnimi koti. Pri njej moram poudariti to njeno posebnost. Pa ni rečeno, da so te posebnosti tako očitne. Lahko so tudi skrite, a mentor jih mora odkriti. Jih upoštevati. Iz njih se človek razvija. Razvoj je namreč mogoč le iz tistega, kar imamo, in ne iz tistega, česar nimamo. Seveda ni nujno, 
da je tisto pozitivno. Tudi iz tega, kar se zdi za človeka negativno, raste učenje. To sicer še ne pomeni, da lahko pristanemo na to, da študenti delajo le tisto, kar zmorejo in želijo. Tehnik se morajo učiti, vendar za božjo voljo, dopustimo, da ima vsak svoj izraz. Ne smemo dopustiti, da bi vsi postali kopija nas samih. To bili dobro za dobre kopiste... za slikarje pa ne.

\section{A. S.: Koliko naj bo mentor navzoč v delu svojih študentov?}

No, tudi tu sem prišel do novih spoznanj. Dolgo sem poskušal razumeti, kaj in koliko storiti. V začetku, kar nekaj let, smo delali vsi vse lepo po vrstnem redu. Dolgo smo se zadržali ob tihožitju, predolgo ... Sprva so moji študenti pričakovali, da bom vse postoril za njih. Urejal tihožitja, zbiral motive. Kasneje sem spoznal, da je bolje, če za vse poskrbijo sami. To jim kar dolgo časa ni bilo všeč. Spominjam se, da sem jih namenoma pustil same. Godrnjali so, češ da se sprehajam naokoli in le vsake toliko časa vržem oko na njihovo delo. Dam pripombe. Zlagoma pa so se naucili verjeti sebi in svoji zaznavi in vrednotenju. Oprli so se tudi na kolege in tudi na njihove komentarje. Moje strokovno mnenje je bilo le eno od mnenj. Še več, naredili smo skupen program. Spoznal sem, da ljudi, ki so že izpolnili svoje obveze do družbe, ne morem priganjati tako kot mlade. Njihova naloga je, da jum je dobro, da se dobro počutijo. Da se pod jesen ukvarjajo z njim najljubšimi rečmi. Spoznal sem, da nimam pravice siliti jih. $\mathrm{Pa}$ sem pričel tiščati ljudi le v tisto, kar jim je šlo dobro. sNe delajte s tistim, česar ne občutite«, imam navado reči, in »Uporabljajte le tiste materiale, ki vam ležijo ...«.

Mentor mora biti avtoriteta. Kaj potrebuje za to, da avtoriteta postane? Mora biti sposoben ustvariti odnose in seveda imeti tudi malo znanja. To se razume. S čim sem jaz lahko postal avtoriteta $v$ očeh mojih študentov? Kot slikar gotovo ne. Avtoriteto sem črpal iz mojii prešnjih odnosov z učenci in drugimi ljudni. Večina slikarskih skupin je močno vodenih. Vendar, šele ko mentor odvrže to vodstveno krinko, postane $v$ očeh swojih študentov ne zgolj navidezna, ampak prepoznana avtoriteta.

\section{A. S.: Prej ste omenili, da je vašim študen- tom slikanje način bivanja. Kako ste to do- segli?}

Po nekaj letih se mi je zadelo, da se nikamor več ne premaknemo. Navadili smo se drug drugega. Vsak torek so pripotovale in odpotovale mape, $v$ njih slike, $\mathrm{ki}$ so jih naredili pri urah. Kaj pa vmes? Vmes ni bilo ničesar. $» P a$ kaj bi vi sploh radi? «, sem jih spraševal. $\gg P a$ kaj boste delali ali ne boste delali? Kmalu sem spoznal, da sem jih pravzaprav premalo obremenil, da bi

Mentor mora biti
sposoben ustvariti
odnose, biti mora
avtoriteta.
jim bilo vse skupaj še zanimivo. Kako naj postanejo slikarji, če s slikanjem ne živijo! Če s slikanjem in razmišljanjem o barvah, motivih, oblikah ni prepojeno vse njihovo življenje! \$Nikoli ne bodo slikarjik, sem se zgrozil. Ja, še zmeraj mi je bilo lepo z njimi razpravljati o slikanju, kajti mene, ki nisem mogel slikati dovolj, je to držalo v nekakšni slikarski kondiciji. Moje poklicno življenje me je namreč že vodilo proč od slike in žal mi je bilo. $\mathrm{Pa}$ vendar, zazdelo se mi je, da ne napredujemo več. Potem mentorja pač ne potrebujejo več, sem si rekel. Jaz sem svoje zmožnosti izčrpal. Kaj storiti? Oditi, jih zapustiti? Tedaj mi je šinila v glavo misel. Delali bodo doma, slike bodo prinašali in jaz jih bom razčlenil, jih komentiral. Iz tega se bomo vsi skupaj marsičesa naučili. Malo so godrnjali, kot da jih oče zapušča. Dva člana sta tudi odšla. Drugi so ostali. Nekaj časa niso prav vsi prinašali slik $v$ analizo. Pa so kmalu spoznali, da se bodo tako tudi izločili iz skupine. Zlagoma so začeli delati. In ne samo delati, slikati, marveč tudi živeti kot slikarji. In to je bil pravzaprav 
moj cilj. Tisto leto so naravnost eksplodirali. Sprostila se jim je ustvarjalnost. Zaplapolala so njena krila. Nisem jim več vodil roke. Zdaj so sami vrednotila svoja dela. Najprej so jih vrednotili čustveno. V̌seč mi je ali pa ni mi všeč, kasneje še vse drugače. Mislim. da takrat, ko slušatelji prično sami delati, ko pridejo do svojega izraza, da se takrat tudi mentor marsičesa uči ... Še več, ugotovili so, da jim ni treba slikati, da bi zadovoljili moja pričakovanja, osvobodili so se.

A. S.: V vašem pripovedovanju je čutiti tudi, da ima skupina v vaših očeh posebno moč.

Ja, prav vse se dogaja v skupini. Skupina pa ni nekaj statičnega. Ni zbor posameznikov, Je živ organizem. Skupina nihà v razpoloženju. Postavlja si cilje, jih doseže. Dokler traja napetost, da bi dosegli vredne cilje, je vse lepo

Mentor zopazovanjem odkrije, kako lahko iz študentov izvleče najboljše. in pray. Tik pred ciljem se vsi počutijo kot pred veliko odločitvijo. Napeti so. Takrat mora mentor vedeti, kako napetost blažiti. Včasih člani skupine postanejo tudi tekmovalni. Pojavlja se ta blaga agresivnost,

ki jo je treba speljati v skupen dosežek. Iz negativne energije je treba narediti pozitivno. Potem sledi nastop v javnosti. Kritike. Odmevi. Zadovoljstvo po dobro opravljenem delu. Sklepi, da bo v prihodnje še bolje. Za tem pa upad zanimanja, počitek ... Vsak teden ima svojo notranjo dinamiko, vsak mesec, vsak letni čas. Življenje skupine je, tako kot življenje slehernega človeka, podvrženo nihanju. Pomembno je, da mentor začuti ta notranji utrip in ritem. Da ne gre proti njemu. Pa vendar je pomembno tudi to, da zna postavljati vredne cilje. Nuditi oporo.

\section{A. S.: Česa bi si zdaj želeli glede svoje sku- pine in kaj mislite o prihodnosti? \\ Želim si, da bi jim tudi strokovnjaki, kritiki, politiki in drugi posvetili pozornost, ki si jo}

zaslužijo. »Moten odnos« do starejših vsako leto preverjam, ko razpošiljamo vabila na razstave v KUD France Prešeren. Le redko se oglasijo predstavniki javnih občil. Tako je bilo vsa zadnja leta. Krivično se mi zdi v primerjavi $z$ drugimi, ki dostikrat dajo precej manj od sebe, pa jih vendar okolje opazi in upošteva. Rad bi, da opravimo kakšno raziskovalno nalogo, ki bi spoznanja te skupine odkrila, popisala, vredna spoznanja pa posplošila. Sicer pa bomo slikali še naprej in kmalu bosta nastala zbornik in katalog. Tudi to bo naša izkaznica v javnosti. Odziv javnosti pa vsi potrebujemo kot kruh. Moramo dokazati, da - četudi v starem telesu - duh ne zamre, Sam sem prepoznal duha mojih starih študentov kot mladega in voljnega, čeprav se ne ukvarjajo več s poklicem. No, tudi to ne velja. Gospod, ki je nuklearni fizik, še zmeraj piše članke in še dandanes oblikuje svoje strokovno področje. prav tako navdušeno pa tudi riše.

\section{A. S.: Če bi strnili razmišljanja o mentorju in mentoriranju, poučevanju in učenju, kaj bi dejali?}

Mislim, da z opazovanjem mentor odkrije, kako iz študentov izvleči tisto najboljšè, kar lahko razvijejo. Pa tudi, kako jih prisliti v delo. Treba je začeti pri ljudeh. Tam se vse začne. Za vse nas velja, da smo krivi, dokler ni dokazil, da nismo krivi. S tem pogledom se ne strinjam. Jaz mislim, da smo vsi nedolžni, dokler se ne dokaže, da smo krivi. Če zdaj to prenesem na študente. Dokler se ne izkaže, da nečesa po mnogih poskusih zares ne zmorejo, moramo verjeti, da zmorejo in se lahko razvijejo. Študente je treba pripeljati v stanje samostojnega dela in izraza. Seveda jim je treba prej dati popotnico. Vendar le tako, $v$ samostojnem delu in vrnitvenih informacijah lahjo ugotovijo, da so odrasli in neodvisni, da ni treba delati tako, kot si želi mentor, zadovoljevati njegove potrebe in pričakovanja, se pripravljati zanj ali za koga drugega. Preprosto se ni več treba pripravljati za kogarkoli. 
Mentor mora v nekem trenutku izpustiti študentovo roko. Ne sme je več voditi. Tako zlagoma študentova nesamozavest, ki se kaže $v$ besedah $\otimes \mathrm{Ne}$, saj to je čisto zanič ... «, plahni. Navadi se, da so stvari lahko tudi slabe, zato da so kasneje boljše. Mentor pa mora tiščati v ljudi, v tisto, v čemer so dobri. Ne sme jih síliti, da delajo s tistim, česar ne čutijo. Delajo naj le tisto, kar jim je ljubo. Mentor se mora kmalu po tistem, ko skupino malo spozna, pričeti ukvarjati s pravimi problemi. Opustiti mora svoje ambicije. Ambicije ga delajo nadzorujočega, vodijo vse njegove odločitve, tako mimo ljudi. Kadar skupina popusti in prične nekaj »mleti«, pa nič ne reče, se mentor začne spraševati, kaj naj z njimi sploh počne. Tedaj spozna, da so njegovi študenti premalo obremenjeni za sposobnosti, ki so jih že razvili. Mentor mora biti avtoriteta. Zgradi jo, kot sem že dejal, iz poznavanja odnosov in znanja. Odnosi so najpomembnejši. Razmerje med mentorjem in študentom ali študentom in mentorjem se zgradi iz odnosa. Mentor je lahko dober slikar, lahko tudi veliko zna, Vendar mu to še ne nakloni avtoritete, Tako se lahko sproti uči. Tudi jaz sem se. In ker se lahko učimo neskončno, sem še danes, po dvajsetih letih, mentor svoji skupini.

Pogovor je vodila in zapisala doc. dr. Dušana Findeisen 